\title{
Patrick Eisenlohr Religious language and media: Sound reproduction and transduction
}

\section{Introduction}

There is a growing scholarly interest in the intersections of religion and media. This has resulted in a burgeoning literature, initially propelled by the investigation of religion in the public sphere. Directed against the Habermasian notion of the public sphere as secular, in recent years a considerable number of studies have shown that religious actors not only form an integral part of publics around the world, but that contemporary religious movements make full use of the techniques of mobilization and the cultivation of sociability among strangers characteristic of public spheres (Meyer and Moors 2006; Hirschkind 2006; see Eisenlohr 2012 for an overview). Moreover, this move has coincided with another reconsideration of the notion of the public sphere, criticizing its overly strong emphasis on deliberation. While scholars have pointed to the deliberative dimensions of religiously grounded interventions in public debate, they have also emphasized public spheres' embodied and visceral dimensions (Meyer 2004, 2008; de Abreu 2009; Oosterbaan 2009) as evident in entertainment, advertising, and religion, which in many cases also overlap. Another strand of research on religion and media has taken a different point of departure, i.e., the intrinsic connections between religion and media (de Vries 2001: 28; Stolow 2005). Religion is cast as a process of communication and interaction between human actors and non- or semi-human actors or forces located in a religious otherworld. Such interactions necessarily involve media, including their material and technical dimensions, as is evident from uses of scripture, sacred objects, images, and more recently also various forms of electronic and digital media that enable and enhance the interaction with the divine (Engelke 2010; Eisenlohr 2009, 2011; Morgan 2005; Schulz 2012).

In many, if not most religious traditions, language plays a pivotal role in making a religious otherworld accessible. Linguistic interaction and other forms of language use are ubiquitous in the interactions of humans with actors and forces in religious otherworlds, however conceived (Bauman 1983; Bowen 1993; Keane 1997, 2004; Eisenlohr 2011; Robbins 2001; Tomlinson 2004 and 2014). Despite this, research on religion and media and religion and language have

Patrick Eisenlohr, Georg August University, Göttingen

https://doi.org/10.1515/9781614514329-016 
to date largely constituted separate literatures. In particular, much recent work on the materiality and aesthetics of religion has paid great attention to media (Hirschkind and Larkin 2008; Meyer 2010; Morgan 2010) but tends to reject language and language-based semiotics as analytical perspectives. This is surprising, not just considering the obvious materiality and aesthetics of language, whether in oral performance or textual form, but especially in light of the fact that key characteristics ascribed to media also apply to language. Even more to the point, some recent debates in media theory were already prefigured in 19th-century debates about the relative transparency of language as a medium, a situation that the German linguist Ludwig Jäger has described as media theory's "forgetfulness of language" (Sprachvergessenheit der Medientheorie) (Jäger 2000).

Paying attention to these intriguing parallels, in this chapter I discuss how contests about religious language have revolved around a contrast between, on the one hand, a preference for literalism, with its emphasis on reference and denotation; and on the other hand, a valuation of the poetic functions of language and its material properties. Turning to the issue of electronically mediated language in religious settings, I discuss how sound reproduction technology has become part of religious practices, drawing on my research on language and media among Mauritian Muslims. I analyze how electronic mediation of voice is intended to bring members of this community closer to the divine; and I show how the material dimensions of language, which I seek to capture under the logic of transduction, sustain religious interaction. Uses of sound reproduction aim to narrow the gap between Muslims and the divine by creating sonic presences that, in turn, provide affordances for particular ideas about religious language and media.

Media exist, because alterity exists. Mediation is the processes linking differing actors, objects, or social formations across qualitative, temporal, or spatial gaps. Such processes of mediation require, in order to unfold, some medium, which always has technical and material dimensions. Modern media theory has focused in particular on two aspects of media. On the one hand, theorists have highlighted the ways in which modern media enable the shrinking of space and time, so as to enable a relative immediacy in interacting with others (Harvey 1989; Tomlinson 1999). Here, in its overcoming of space and time, the medium functions so smoothly that awareness of it recedes into the background, giving way to the seemingly immediate presence of whatever it is that it mediates. On the other hand, media scholars have also analyzed how media forcefully assert their presence to such an extent that they constrain and override human agency. One of the fundamental insights of media theory, that the "medium is the message" (McLuhan 1964), stresses how the modalities and technologies of mediation have a shaping impact not only on their direct objects but also on a broad array of 
human relations. Some have regarded this propensity of modern media to transform social worlds and human subjectivities in their own image as a danger to established social contexts and human creativity (Baudrillard 1994). This has culminated in dystopian visions in which the perpetual acceleration of social life brought about by modern media turns humans into "invalids" that lose control of their lives to media machines that will in the end, in the guise of nanotechnology, even invade and colonize their bodies (Virilio 1998: 20, 179). Other media theorists have cast such developments in a far more positive light, celebrating a fusion of humans with machines that in the final instance will do away with human subjectivity and its attendant symbolic forms and meanings. "So-called man" will then be shaped by technical standards (Kittler 1997: 133) and eventually be liberated from the "yoke of subjectivity" (Kittler 1993: 181). ${ }^{1}$

It is clear that a great range of objects, apparatuses, or institutions can be treated as media, which leads to the danger that the notion of media may become too broad to be meaningful. Nevertheless, an overview of scholarship on media suggests that, among the manifold phenomena that have been designated under this category, there is perhaps one key quality that they have in common. This is the oscillation between great perceptibility, as in the assertion of their presence as they constrain and shape human agency and subjectivity, and their virtual disappearance in the act of functioning, enabling an air of immediacy across gaps of alterity (Bolter and Grusin 1999; Eisenlohr 2009; Krämer 2008). ${ }^{2}$ Pointing to their interconnectedness, Jay Bolter and Richard Grusin have called these two states of media "hypermediacy" and "immediacy," respectively, stressing that "our two contradictory logics not only coexist in digital media today, but are mutually dependent. Immediacy depends on hypermediacy" (Bolter and Grusin 1999: 6). In order to operate successfully, media need to withdraw from experiential awareness, giving full presence to whatever it is they mediate. Whether working on a computer while looking at its screen, listening to reproduced sound, or making a phone call, if media operate successfully in expected ways, they, including the

1 Lacanian psychoanalysis is a likely influence in Kittler's perspective on subjectivity as a "yoke," whose removal is equivalent to liberation.

2 John Durham Peters (1999: 63-108) has shown how in the 19th and early 20th centuries desires for immediate "spiritualist" communication between humans and humans and the dead were closely connected to a fascination with emerging electronic media such as the telegraph and radio. In a related vein, Jonathan Sterne's (2003) history of the origins of sound reproduction has demonstrated how this technology grew out of a cultural milieu obsessed with the idea of hearing the voices of the dead. These "spiritualist" sensibilities are an important modern source of the connection between whatever counts as "new" media and desires for immediacy, or in Sterne's terms, the search for a "vanishing medium." For a related discussion, see Anderson Blanton's essay in this volume. 
technical apparatuses and networks that constitute them, drop from awareness, while media users' perception is focused on the images, the sounds, or other phenomena mediated through them. In fact, the propensity of acts of mediation to temporarily erase themselves in the very act of mediation is one of the conditions of possibility for their success. However, if a computer malfunctions, and the screen image of the person in another part of the world with whom we are having a conversation disappears or freezes; if noise interferes with the enjoyment of recorded music; or if a cell phone call drops, the respective medium suddenly reenters awareness, and its users' perception redirects towards its obstinate material existence and infrastructure. Media therefore have the tendency to shift between states of perceptibility and disappearance. Desires for maximally performing, optimally transparent and therefore "vanishing" media notwithstanding, such oscillation is ultimately impossible to suppress and a fundamental characteristic of any medium. Wishes for immediacy go hand in hand with the development of ever more complex media apparatuses. These apparatuses become perceptible when they are experienced as overriding the control and agency of humans. Sudden reappearance, disrupting any impression of immediacy is also caused by the vulnerability of media, their inevitable tendency to periodically malfunction. In the underperformance or failure of media, the trace of the material suddenly thrusts itself into the awareness of the media user. "Noise" as understood by information theory is a trace of the materiality of the medium, "it protrudes into perception 'ecstatically,' haunting vision, hearing, or the sense of tactility and maintains itself 'in presence' to such a degree that it causes the mediality of the medium to "break"" (Mersch 2002: 65-66; see also Krämer 2000).

For those familiar with 19th-century European debates about language, these deliberations about media strike a familiar note. In fact, the notion of media as transparent was prefigured in these earlier engagements with language. According to Hegel, language was of interest precisely because it seemed to be the medium of thought that was most transparent, in the sense that it left the least imprint of its own on what it mediates.

Now the symbol is prima facie a sign. But in a mere sign the connection which meaning and its expression have with another is only a purely arbitrary linkage. In that case this expression, this sensuous thing or picture, so far from presenting itself, brings before our minds a content which is foreign to it, one with which it does not need to stand in any proper affinity whatever. So in languages, for example, the sounds are a sign of some idea, feeling, etc. But the predominant part of the sounds in a language is purely linked by chance with the ideas expressed thereby [....] (Hegel 1975 [1835]: 304)

For Hegel the linguistic sign (often referred to by him as the "word") is "by itself void of significance" (Hegel 1975 [1835]: 88), which enables "intelligence" to 
unfold in a "resistance-free element" (in einem widerstandslosen Element) (Hegel 1970 [1830]: 239 [\$444 Zus.], see also Hegel 1970: 270, Bodammer 1969: 47-50, McCumber 2006: 118-119). These thoughts were further elaborated by Wilhelm von Humboldt, who characterized language as constituted by the connection between sound and idea (Ton und Vorstellung) (von Humboldt 1908: 581-583), a notion that anticipated the Saussurian formulation of the arbitrariness of the sign (Saussure 1983). Yet the notion that languages consist of arbitrary signs was already clearly formulated by Hegel, and can be traced even further back, to John Locke, who argued that the connection between words and ideas is based on a social contract (Bauman and Briggs 2003: 33-34; Peters 1999: 85). The Saussurian sign was a culmination of the dream of language as a transparent medium, in which the material forms and characteristics of the sound have no bearing whatsoever on the ideas and meanings conveyed. In Peircean terms, the Saussurian arbitrary sign would be a symbol, whose link to its object is defined by social convention, as opposed to indices and icons, which derive their meanings from relationships of contiguity and resemblance, respectively. The close parallels between theorizations of language as the medium providing the least resistance to thought and more recent discussions in media theory are striking but are rarely remembered.

The parallels between these earlier explorations of the mediality of language and more recent theorizing in media studies can also be brought to bear on the study of linguistic relativity in the tradition of Benjamin Lee Whorf and Edward Sapir. Whorf famously argued that linguistic categories, in particular grammatical categories, have a pervasive influence on habitual thought, including by reinforcing cultural stereotypes, and can therefore shape thought and cognition in distinct, although non-deterministic ways (Whorf 1956). According to him, language mediates thought in ways that bear testimony to particular formal features of the languages concerned. He distinguished between the "overt" and "covert" linguistic categories involved in such mediation. Overt categories have surface features that make them more readily discernible to their users, such as an always present formal marker of a particular grammatical category, as opposed to covert categories, such as gender in English, or noun classes in Navaho, which largely lack such features as formal markers, and therefore are less likely to enter their users' awareness (Whorf 1956: 88-91). Overt categories are just as involved in the mediation of thought as covert categories are. However, covert categories can influence thought in especially powerful ways, since in contrast to overt categories they largely operate on an unconscious level. A related perspective on the linguistic mediation of thought and the social has been developed by Michael Silverstein. Silverstein distinguishes linguistic forms that are maximally segmentable (like distinct words), can be referentially glossed, and have a relatively 
presupposed quality with respect to their contexts of use (such as when social etiquette makes one expect the use of such forms in a particular interaction), as for example Dyirbal "mother-in-law" vocabulary, ${ }^{3}$ from those that lack these characteristics. Theorizing the "limits of awareness" in language, Silverstein has argued that the former are much more likely to be the focus of their users' attention and awareness, and also more likely to provide a basis for sociolinguistic stereotypes (Silverstein 2001 [1981]). In both of these approaches, work on linguistic relativity and the limits of awareness in language emphasizes a distinction between linguistic elements that function as media in highly perceptible and salient ways, and those parts of language that withdraw from experiential awareness in the process of mediating thought and social relationships.

The Protestant genealogy of a preference for a seemingly "transparent" linguistic medium whose own formal and material features retreat in the face of the meanings and pragmatic effects conveyed is well documented (Keane 2007; Yelle 2013). Hegel's philosophy of mediation, including its implications for the study of language, provides ample evidence for a Protestant bias towards language as a vehicle of spirit whose materiality is minimized. ${ }^{4}$ Protestants also came to be known for their preference for "plain speech" (Bauman 1983) and literalism, that is, an emphasis on the referential content of language. Although Protestant language ideologies are not uniform, “[...] broadly speaking, the Reformation inspired a movement toward literalism, meaning both a valorization of the semantic content of language and a devaluation of its poetic and magical functions, which contributed to the rise of polemics against both ritual and mythological language" (Yelle 2013: 25). In religious contexts, the main "other" of such an approach to language was ritual and poetic language, especially in its Catholic

3 Dyirbal "mother-in-law language" is a register of avoidance and respect that speakers used to switch to when within earshot of their classificatory mother-in-law. Classificatory mothers-in-law used to be taboo relatives for users of Dyirbal. The register did not just involve the use of distinct honorific linguistic forms, such as the contrast between familiar T-forms and respect-indicating V-forms of address in many European languages, but the wholesale substitution of vocabulary by forms specific to the "mother-in-law" register. The register follows the same rules of grammar and phonology as everyday speech, but with few exceptions comprises specific alternate forms for every noun, adjective, verb, and time qualifier (Dixon 1990).

4 A good example for the links between the Protestant cultural milieu Hegel grew up in and his philosophy of mediation is the use of the Biblical term Entäusserung (from Luther's translation of Greek ekkenoun and Latin exinanio 'to make empty, to deprive') in the Phenomenology of the Spirit. There, Hegel uses this term to both refer to the incarnation of God in the Son but also in a related fashion as a general characterization of objectification as one of the necessary elements in the movement of spirit (e.g., Hegel 1986: 566-567, 570; English translation Hegel 1977: 472, 475). See also Eisenlohr (2009: 274-275, 290-291). 
genres, but subsequently also extended to a wide array of religious others in the course of colonial expansion: "Poetry was held responsible for the personifications and polytheism of pagan mythology. The vain repetitions of Catholic and heathen prayers were labeled a form of rhetoric premised on the belief in an anthropomorphic deity, one susceptible to human persuasion and given to work magic in the world" (Yelle 2013: 9).

This suggests that the dialectics of mediation and seeming immediacy also apply to language. Protestant language ideologies have been described as focused on the referential function of language, interiority, sincerity, and a suspicion of ritual language or other genres that foreground the materiality of social and historical contexts (Bialecki and del Pinal 2011: 580; see also Shoaps 2002; Crapanzano 2000; Harding 2000; Engelke 2007; Robbins 2001; Bielo 2011). Such language ideologies seek to arrest one moment of a dynamic that is really an oscillation. Language, like other media, alternates between states of seeming transparency and those moments in which the obstinacy of its materiality foregrounds itself.

In religious contexts, one can distinguish a tension between two modes of employing language as a mediator between humans and actors in a religious otherworld. On one hand, there are forms of religious language that emphasize referential meaning in discourse. This perspective on language is close to the Hegelian and Saussurian notion of the arbitrary sign, in which the material and formal aspects of the linguistic sign stand in no inner relationship to signification. According to this semiotic ideology (Keane 2003: 419), the materiality of the sign should be sidelined in accounting for the meaning of discourse, including its pragmatic consequences, in fulfillment of a "project of immateriality" (Engelke 2007: 246) that also extends to language. On the other hand, there are numerous kinds of religious language that are precisely centered on the foregrounding of its material and formal characteristics, such as spells (Kang 2006), ritual registers (McIntosh 2005), which may sometimes be unintelligible to those performing them (Wirtz 2007), genres of ritual lament and wailing (Urban 1988), divination (Du Bois 1993), ritual prayer (Bowen 1993; Corr 2004; Mahmood 2001), and healing (Wilce 1999). The latter manifestations of religious language are indissolubly bound to the effects and uses of such linguistic genres. Even more so, the materiality of such religious discourse and genres is seen as indispensable for the production of its intended effects, namely to sustain desired interactions with a religious otherworld (Keane 1997; Kuipers 1990; Du Bois 1986). In some of these genres of ritual language, such as mantras (Staal 1989; see also Yelle 2003) the referential meaning of discourse may even be completely irrelevant.

The two overall types of religious language I discuss here are not always mutually exclusive. In some kinds of religious language, they may be combined 
in interesting ways. Yoonhee Kang has described how Petalangan ritual language in Indonesia is both informed by referentialist language ideologies and the valuation of the material and performative dimensions in ritual language (Kang 2006). Among anthropologists, Christian contexts have provided illustrations for the historical shift from a performativist to a referentialist language ideology (Keane 2007; Robbins 2001), a phenomenon also attested for Islamic modernist settings (Wilce 1998). In contrast to such permanent shifts from one mode of religious language to another, Petalangan and Sikh engagements with religious language, the latter as decribed by Myrvold (2015), provide evidence for a routine alternation between the principal two modes discussed here. Among Sikhs, the referential content of the Guru Granth Sahib is highly valued but the scripture is also a "living guru" whose presence is activated by chanting and singing the text. Another way of being close to the living guru is by ingesting sweetened water that has been consecrated by chanting hymns from the Guru Granth Sahib (Myrvold 2015), a practice that involves the transduction of religious language, a theme I will discuss at greater length below, providing discussions of the performative effects of religious language with a new twist. ${ }^{5}$ Recitation of the Qur'ān is another very prominent example of combining attention to referential content with a stark foregrounding of the poetic patterning and performative dimensions of ritual language (Gade 2006). In Islamic settings, this alternation may also be mapped on different genres of religious language in different linguistic codes. In the Mauritian case I will discuss later in this chapter, referentialist sermons (khutba) in the main vernacular language, Mauritian Creole, stand next to Urdu na't, devotional poetry in honor of the Prophet Muhammad, with its characteristic emphasis on poetic form and performative effects. As in the case of Qur'ānic recitation, the alternation between referentialist and "formulaic," performative sensibilities towards language is often a matter of situational focus, potentially susceptible to rapid shifts.

In other words, religious uses of language clearly demonstrate that the mediality of language, here understood as bridging gaps between human actors and non- or semi-human actors and forces in an often imperceptible religious otherworld, feature a very similar alternation between salience and disappearance of the medium. Those kinds of religious language that heavily emphasize the referential content of language over its material form provide examples of a withdrawal of language as a medium. As there appears to be no necessary link between its material characteristics and its meanings or pragmatic effects, such

5 In a range of Islamic contexts a similar practice of "drinking the Qur'ān" is also common (El-Tom 1985; Wilkens 2013). 
instances of religious language resemble the ideal of a "transparent" language, a perfect mediator that leaves no traces on what is being made accessible through it, thereby erasing itself in the act of mediation. In contrast, those linguistic interactions with a religious otherworld, where the materiality of the sign is intimately connected to its pragmatic effects, stand for a mode of mediation where language as an "in-between" between humans and the divine crucially shapes what is being mediated through it. As is the case in poetic forms of religious language, the formal and material dimensions of language are maximally foregrounded, leading to great salience of the medium. The oscillation between relative imperceptibility and salience of the medium thus seem to be constitutive of mediality as such, uniting language and other forms of media technology.

\section{Sound reproduction as mediation}

How do the medialities of sound reproduction and language relate to each other? To start with sound reproduction, the dream of a "vanishing medium" that perfectly and transparently conveys sounds, such as voices, has accompanied the development of this technology for a long time. Early on, the "fidelity" of reproduced sound and the concomitant suppression of "noise" played a prominent role in marketing strategies of the gramophone industry (Sterne 2003: 215-286), perhaps most famously captured in the 1899 advertisement image of The Gramophone Company (which subsequently became RCA), "His Master's Voice," featuring a dog approaching the funnel of a gramophone placed on what looks like the top of a coffin, supposedly emitting the recorded voice of its owner (Sterne 2003: 302). Jonathan Sterne has argued that the invention of sound reproduction technology was a response to a cultural milieu in late 19th-century North America and Europe fascinated with spiritism and the idea of listening to the voices of the dead (see also Schmidt 2000). At the time, many found the acousmatic voice (Chion 1994), meaning one separated from its source, thrilling and mystifying. While the novelty of acousmatic voices has long since vanished, their presence having become a banal feature of modern lifeworlds instead, the ability to technically reproduce voice and sound has added a key new dimension to the longstanding role of language in mediating between religious practitioners and religious otherworlds.

Religious practitioners in the most diverse contexts in the world today use technologies of sound reproduction, not just to enhance the social relationships that the circulation of religious language brings about (Greene 1999; Manuel 2008; Schulz 2008), but also to support attempts to reproduce authenticated religious 
discourse conforming to particular generic types, and thereby also to enter in proximity with the divine (Qureshi 1995; Hirschkind 2006; Brennan 2012). This may be done through entextualization, meaning the process of lifting a chunk of discourse out of a given context and reinserting it into new contexts (Briggs and Bauman 1992). The bounding and reproducing of a recognizable chunk of discourse turns it into a "text," but far from fixing it, entextualization as the lifting and grafting of discourse from one context to another emphasizes the processual qualities of texts. (See Paul Copp's paper in this volume for an illustration of this process.) Entextualization can be done in such a way that the gap between the context of origin and the target context is minimized, or it can result in a highlighting of what Briggs and Bauman have called "intertextual gaps."

In my research on media, voice, and Islam in Mauritius, sound reproduction, first in the form of audiocassettes, and more recently audio-CDs and $\mathrm{mp} 3$ files, was widely used in the circulation of Urdu devotional poetry in honor of the Prophet Muhammad. My interlocutors' interest in sound reproduction was in the saturation of new, everyday contexts with this genre of poetry that this technology enables beyond the boundaries of the ritual events where recitation normally takes place. Another field of deployment for sound reproduction was the preparation for such ritual events, where the circulated recordings of well-known and trained na't khwan 'reciters of the na't genre' represented models of vocal performance to be emulated. Mauritian Muslims accord great importance to the appropriate vocal style for the success of the performance, which is intended to bring them closer to the Prophet, and ultimately to God, by expressing deep affection for the Prophet and asking for blessings to be showered on him. While listening to recordings of this devotional poetry featuring what my interlocutors felt were the right movements of pitch, volume, and vocal timbre, they prepared their own performances. That is, they used sound reproduction technology as an aid for the faithful and authentic entextualization of poetic discourse, in which any gaps between the context of the performance of origin and that of the target performance could be minimized (Eisenlohr 2006 and 2010). In semiotic terms, sound reproduction technology thus features as a device that supports the production of tokens that fit a type, here the generic conventions of the na't genre. The great care taken in the passing on and circulation of religious language is striking, as is the role of sound reproduction in these processes. The uses of sound reproduction are informed by a longstanding Islamic sensibility for the accurate transmission of religious texts. Accordingly, the validity and perceived authenticity of particular texts, such as hadith, the record of the deeds and words of the Prophet and his companions, is reckoned through a detailed examination of their chains of transmission (isnad) spanning centuries, and ideally linking present-day Muslims to those directly familiar with the Prophet and his companions through 
chains of reliable and morally trustworthy interlocutors (Graham 1993: 506-508). This paradigm of isnad also applies to the transmission of sacred objects, and can be extended to textual genres other than hadith. We could say that for many Mauritian Muslims, and Muslims elsewhere, sound reproduction technology has been domesticated into an established and powerful paradigm of language as mediating between Muslims and their Prophet, and ultimately God.

It is important to realize that such uses of technology in the linguistic mediation of the divine draw on particular assumptions about the medium employed. Using sound reproduction as a means to ensure the faithful and authentic entextualization of religious discourse mobilizes the notion of sound reproduction as a "vanishing" medium that leaves no traces on what it mediates, that is a mere "intermediate" rather than a "mediator" in Latour's terms (2005: 39). Such media ideologies drive the domestication of sound reproduction technology, including its latest digital versions in established ritual contexts, as in the cultivation of devotional poetry in honor of the Prophet Muhammad.

Another important way in which media technologies such as sound reproduction can shape the linguistic mediation of religious worlds is by refiguring participant roles in discourse. Ever since Goffman's explorations in that field, it has been clear that the "I" of discourse can take several forms that in turn can be assigned to particular participant roles and therefore forms of agency in discourse. To this effect, Goffman distinguished between composer or "ghostor" (akin to ghostwriter), the originator or sponsor who assumes responsibility for the speech act, and animator or relayer who is actually performing the act, all of which can be combined in a single person, or be taken up by different actors (Goffman 1974: 517-520; Levinson 1988; Irvine 1996). Most importantly, participant roles frequently shift depending on interactional context. In religious settings, the agency in discourse is of great significance, as for example particular forms of ritual language may be considered words of the ancestors or discourse uttered by deities, even if performed by human actors in a ritual setting. Here, the complex nature of the "I" in religious language is evident (Urban 1989), as well as the fact that actors in such settings can not only inhabit different participant roles in linguistic performance, but that the assignment of and expectations of such roles are of supreme importance for the efficacy and meanings of religious discourse. Uses of media such as sound reproduction can influence the assignment of participant roles, and thus reinforce established authoritative agencies in religious language, but can also result in anxieties about whose agency it actually is that is manifest in particular religious speech acts and discourses. In fact, the anxiety of and fascination with media regarded as "new" often lie in their propensity to reconfigure participant roles in interaction (Gershon and Manning 2014: 562-564). 
For example, the perceived efficacy of na't recitations also lies in the assumed origins of the poetry as composed by renowned saint-poets, who composed na't in moments of spiritual intensity, such as when confronted by the presence of the Prophet himself. The poetry features an array of deictic makers, such as personal pronouns, spatial and temporal qualifiers, which together with the poets' pen names points to such authoritative contexts of origin. The recitation of poems preserves these indexical markers of a context that is located elsewhere in space and time. It is thereby an act of transposition (Versetzung), to use Karl Bühler's term (Bühler 1965 [1934]: 134-140; see also Haviland 1996; Shoaps 2002); that is, the insertion of a text into another discursive event in a way that indicates the former's origins in another spatial and temporal context. The performances also feature a discursive "I" expressing deep devotion and affection for the Prophet. Reciting performers therefore combine several participant roles. This is because the performers animating the poetry seek to align their agency with the authoritative saint-poets who were considered the composers of nat, and also with its responsible originators. This merger is unstable and requires constant support, notably through performing in ways considered appropriate and authentic. This dimension of authenticity does not just extend to the texts themselves, but very importantly also to the style and modalities of vocal performance. Mauritian Muslims take audio recordings of na't poetry by renowned na't khwan to be authoritative models of the vocal qualities that the performance should have, but that printed compilations of this poetic genre cannot provide. Audio recordings by esteemed performers are thus treated as a way to safeguard and authenticate na't performances in ways that align with and do justice to their assumed context of composition by saint-poets. Given the poetry's array of formal features pointing to these assumed origins, such uses of sound reproduction therefore become part of the indexical field of deictic reference (Hanks 1992). In this way, they also help to support the merger between the participant roles of composer, originator, and animator that those cultivating the genre aim for, which in turn enhances the performance of the poetry as a form of intercession with the Prophet, and thus mediates between Muslims and the divine. The question of media regimenting, or at least influencing the distributions and shifts of participant roles in religious language also has important implications for the larger question of the mediality of language in religion. As my example suggests, the appropriate regimentation of participant roles is crucial for the efficacy of religious language as a mediator of the divine, and uses of technology such as sound reproduction can intervene profoundly in this process.

$\mathrm{Na}$ 't recitation also demonstrates that in religious language there is another kind of oscillation between salience and relative disappearance of the medium that is different from the modality I have discussed earlier. This mode is different 
from the relative perceptibility of linguistic forms as in "overt" and "covert" categories in Whorfian terms, or as in Silverstein's "limits of awareness." In fact, as far as the na't genre is concerned, its structure highlights the formal and material properties of language throughout, because of its web of metric, semantic, and phonetic parallelisms that is the hallmark of poetic language (Jakobson 1960). The additional dimension of the mediality of language I want to point at here relates to the faithfulness to established generic forms and norms of appropriateness in discourse, and the violation of such norms in certain linguistic performances. In technical terms these are matters of presupposed indexicality in the sense of being based on context-specific presuppositions of the co-occurrence of linguistic and non-linguistic signs, and departures from it as interactions unfold, as performers aim to perform language that corresponds to the expectations connected to the generic model of na't, or, put differently, to produce tokens of a type (the respective poetic genre). This requires a success in achieving the "correct" ways of entextualizing discourse and regimenting participant roles that actual performances of na't do not always meet. For example, according to many, the vocal style and timbre of na't recitation should not remind one of film songs. In Mauritius, however, Hindi film ("Bollywood") entertainment is extremely widespread, and its music sometimes influences the way some na't khwan recite the poetry. To an even larger extent, they have also shaped audiences' aesthetic sensibilities and expectations. Sometimes, recitations involve elements that are considered "film style" (filmi taraz), and that in turn renders the performance invalid for some, turning its perceived spiritual benefits into their opposite.

Following this example, I suggest that the mediality of language also consists in the alternations between the unfolding of the performance in expected ways, and moments where this is not the case. ${ }^{6}$ This alternation does not just occur in relation to the expected relationships and correlations among the linguistic signs that make up the poetic text, but also involves relationships of co-occurrence between linguistic and non-linguistic signs of the performance, such as the participants' social identities and their bodily composure and spatial positions, qualities of the voice, and the features of the overall setting of the event. Instantiating all these complex sets of expected correlations and co-occurrences in performance is a delicate achievement always subject to

6 This alternation is similar to what Bauman and Briggs (1992: 149) have called a minimizing and maximizing of intertextual gaps. Bauman and Briggs have described these two movements as potentials of textuality that represent different strategies of establishing authority. I would go even further, suggesting that the two movements also represent the key modes of language's functioning as a medium of socio-cultural worlds, and point to features that language shares with other kinds of media. 
failure. As long as performances unfold according to such situational and generic expectations, the linguistic medium draws little attention to itself as the mediator that enables interactions with the divine. However, the relative perceptibility and disappearance of language as a medium resembles an aggregate state in flux, which can change from one moment of a performance to another, as a performative event that unfolds in situationally expected ways suddenly departs from expectations. Then, the smooth functioning of language as a medium of the divine is disrupted, and reappears as an obstinate medium pushing itself into the awareness of those engaging with religious otherworlds. When, for example, the performance of na't blends with musical elements from Hindi films, the relative "transparency" of language as a medium evaporates, and attention will be redirected to the medium and its inappropriate formal and material aspects, as they suddenly stand in the way (at least for some listeners) of a rapprochement between practitioners and the divine. Such evaluations of appropriateness are of course perspective-bound, they may not be shared by all present. This is also the case in my example, because even though many Mauritian Muslims - and all 'ulema concerned - reject filmi taraz in na't, other Mauritian Muslims see no harm in it. This implies that the mediality of language, at least as far as the dimension of presupposed indexicality and creative deviations from this are concerned, depends to a large extent on the shifting contexts and perspectives of such judgments of appropriateness.

\section{Media, voice, and transduction}

In the contemporary study of religion, the latter's material dimensions have lately gained much attention (Meyer 2014; Meyer and Houtman 2012); in fact 2005 saw the launch of a journal Material Religion specifically dedicated to exploring this key aspect of religion. While much of the work that has followed this direction of research has paid close scrutiny to media and its technical aspects, far less attention has been spent on the materiality of language in religious settings. How do we relate the material aspects of language with other media when it comes to the analysis of religion? In order to address this question, uses of sound reproduction technology in religious contexts, such as those I investigate in this chapter, may provide useful leads.

Sound reproduction can foreground the materiality of voice (Harkness 2014; Weidman 2014). In relation to both sound and voice, sound media open up a different perspective on the materiality of language since they involve transduction, the transfer of energy from one state into another. Media technologies 
convert discourse into different material modalities. For example, writing transduces sonically manifest language into a visual register, while sound reproduction technology transduces sound, which in case the medium through which it travels is air involves differences in air pressure, into electric signals that enter an analog or digital apparatus of storage, and are converted back into sound again when a recording is played. These transductions of energy into different states are very consequential in religious mediation through language, and are closely connected to religiously grounded notions about language. ${ }^{7}$ We have seen that Mauritian Muslims value sound reproduction technology because they regard this as a means to faithfully reproduce sonic tokens that conform to their expectations of the na't genre, above all regarding the qualities of the reciting voice. Although written compilations of na't exist, they are treated as an aide-memoire only; since they reduce the poetry to its textual content, they cannot substitute the sonic power of the reciting voice that is regarded as crucial for the success of the performance. Therefore, those engaged in the performance of na't show a strong preference for the storage of sonic tokens in order to ensure the appropriate entextualization and transmission of this devotional genre, as opposed to their transduction into a visual register through writing. Mauritian Muslims who appreciate na't treat sound reproduction as a technical solution for the problem raised by the high value placed on the perceived authenticity of vocal qualities in religious performance.

The conversion of energy from one state to another that transduction effects can operate as a bridging of various gaps in the interaction with the divine. As Webb Keane has recently argued, forms of transduction such as writing can overcome gaps between different ontological realms, such as happens when a "message" from an imperceptible religious otherworld appears in writing or as a material object in the world where human religious practitioners find themselves. Transduction can thereby also bridge gaps related to differences in agentive capability, such as those between humans and gods (Keane 2013). Transduction, however, not only effects a connection between disparate realms and actors, but also engenders new phenomena along the way. According to Gilbert Simondon's (1992 [1964]) formulation of transduction as a process of "individuation" through

7 While all production of vocal sound and its perception revolves around physical processes of transduction, in my analysis I specifically use the notion of transduction as the core technical process in sound reproduction (Sterne 2003: 22, see also Helmreich 2007 on sound and transduction). Silverstein's use of the term in contexts of translation goes into a different, more metaphorical direction when he deploys the term to describe the rendering of non-referential meanings into another language (Silverstein 2003). See also Handman (2015: 227) for a related use of transduction as an analytical category. 
which new entities, such as biological, social, and psychological phenomena emerge from an unstructured "pre-individual" milieu, transduction is a highly productive process. Simondon defines transduction as "a process - be it physical, biological, mental, or social - in which an activity gradually sets itself in motion, propagating within a given area, through a structuration of the different zones of the area over which it operates. Each region of the structure that is constituted in this way then serves to constitute the next one to such an extent that at the very time this structuration is effected there is a progressive modification taking place in tandem with it" (Simondon 1992 [1964]: 313). Sonic transduction provides a very concrete example of such a process, in which a domain through which sound propagates is reshaped in a manner analogous to the parts already touched by it. Such reshaping and restructuring then leads to the creation of new entities and phenomena. Here I suggest that shared "religious sensations" (Meyer 2008) may actually be the result of such sonic transductions. Given that sound impacts others who are present at the same moment in a religious setting, it can also generate ineffable feelings of religious community. "Speaking as a kind of sonorous touching" (Csordas 2008: 118) then opens up a perspective on language as sonic events that bodies encounter through processes of transduction. Such transduction goes beyond hearing in the strict sense of the term, as differences in air pressure are registered, not just by the hearing apparatus (which transduces sound waves into electrical impulses sent to the brain), but potentially by the entire body. As the flesh encounters language in such ways, we arrive at a very concrete understanding of language as embodied. The transductions that unfold when sound envelops and penetrates bodies may then be productive in several ways, including through the production of religious feelings and sensations.

The latter aspect, the role of language in the felt dimensions of religion, also points to the rhythmic qualities of language and its sounds, as is especially evident in poetry, as in my example of the na't genre. The rhythmicity of language, but also movement of vocal volume, pitch, and timbre, often result in suggestions of movement. Such movement, as in the coinciding of drumming, voice, and language in several Islamic settings in South Asia (Wolf 2014), has an impact on listeners through the logic of transduction. As a result, musically recited poetry has a special potential to generate bodily sensations though its rhythmic qualities and the bodily movements suggested by it. This is because such religious sounds modify the bodily economy of felt space through their movement (Eisenlohr 2018). As they impact bodies, the sensations generated by such sounds may be intertwined, in turn, with historically grounded religious traditions and their narratives. The rhythmicity and other dynamics of linguistic sounds therefore are another mode of mediating between human actors and the divine. 


\section{Conclusion}

Language enables the circulating and sharing of religious forms and practices, often in conjunction with other media technologies, such as sound reproduction. I have discussed language as a materialization of religion that constitutes social relationships among religious practitioners, as well as relations between human and semi- or non-human actors in often imperceptible religious otherworlds. As language mediates and thereby shapes such interactions, it is often itself subject to further technological mediation. Examining the relationship between language and other media technologies, I have sought to show that both undergo similar oscillations between phenomenological disappearance and the reassertion of their presence as the trace of their materiality. This striking parallel between language and media, although frequently overlooked, is of great relevance for understanding the interplay of language, other kinds of media technology, and religion as interactions with the divine. Further, I have suggested that uses of sound reproduction in religious settings are closely geared to concerns religious practitioners have about processes of transmitting and entextualizing religious discourse, as well as the distribution of participant roles in interactions with the divine. While sound reproduction can support established ideas and paradigms of what language accomplishes in such interactions, its disruptive potential is equally present.

The vocal and sonic dimensions of language provide the most vivid illustrations of language as material and embodied. In ritual settings, they are often credited with the generation of strong religious sensations. I have suggested that the analytic of transduction can illuminate how sound, including vocal sound, can provoke such sensations that might undergird a religious tradition's sense of community. Transduction is also the key mode of operation of sound reproduction technologies. An important part of the sonic dimensions of religion is the rhythmicity of language, above all in poetic and musical genres. Rhythm is sensed in the performance of such genres as suggestions of bodily movement, enacting somatic relationships within religious traditions and with religious otherworlds.

\section{References}

Baudrillard, Jean. 1994. Simulacra and simulation. Ann Arbor: University of Michigan Press. Bauman, Richard. 1983. Let your words be few: Symbolism of speaking and silence among seventeenth-century Quakers. Cambridge: Cambridge University Press.

Bauman, Richard \& Charles L. Briggs. 2003. Voices of modernity: Language ideologies and the politics of inequality. Cambridge: Cambridge University Press. 
Bialeckl, Jon \& Eric Hoenes del Pinal. 2011. Introduction: Beyond logos: Extensions of the language ideology paradigm in the study of global Christianities. Anthropological Quarterly 84(3). 575-593.

Bielo, James S. 2011. "How much of this is promise?": God as a sincere speaker in Evangelical Bible reading. Anthropological Quarterly 84(3). 631-653.

Bodammer, Theodor. 1969. Hegels Deutung der Sprache: Interpretationen zu Hegels Außerungen uber dle Sprache. Hamburg: Felix Meiner.

Bolter, Jay David \& Richard Grusin. 1999. Remediation: Understanding new media. Cambridge, MA: MIT Press.

Bowen, John R. 1993. Muslims through discourse: Religion and ritual in Gayo society. Princeton: Princeton University Press.

Brennan, Vicki L. 2012. Take control: The labor of immediacy in Yoruba Christian music. Journal of Popular Music Studies 24(4). 411-429.

Briggs, Charles \& Richard Bauman. 1992. Genre, intertextuality and social power. Journal of Linguistic Anthropology 2(2): 131-172.

Buhler, Karl. 1965 [1934] Sprachtheorie. Die Darstellungsfunktion der Sprache. Stuttgart: G. Fischer.

Chion, Michel. 1994. Audiovision: Sound on screen. New York: Columbia University Press.

Corr, Rachel. 2004. To throw the blessing: Poetics, prayer, and performance in the Andes. The Journal of Latin American Anthropology 9(2). 382-408.

Crapanzano, Vincent. 2000. Serving the word: Literalism in America from the pulpit to the bench. New York: New Press.

Csordas, Thomas 1. 2008. Intersubjectivity and intercorporeality. Subjectivity 3(1). 110-121.

De Abreu, Maria José A. 2009. Breath, technology, and the making of Canção Nova in Brazil. In Birgit Meyer (ed.), Aesthetic formations: Media, religion, and the senses, 161-182. New York: Palgrave Macmillan.

Dixon, R. M. V. 1990. The origin of "Mother-in-law vocabulary" in two Australian languages. Anthropological Linguistics 32(1/2). 1-56.

Du Bois, John W. 1986. Self-evidence and ritual speech. In Wallace L. Chafe \& Johanna Nichols (eds.), Evidentiality: The linguistic encoding of epistemology, 313-336. Norwood, N): Ablex.

Du Bois, John W. 1993. Meaning without intention: Lessons from divination. In Jane H. Hill \& Judith T. Irvine (eds.), Responsibility and evidence in oral discourse, 48-71. Cambridge: Cambridge University Press.

Eisenlohr, Patrick. 2006. As Makkah is sweet and beloved, so is Madina: Islam, devotional genres and electronic mediation in Mauritius. American Ethnologist 33(2). 230-245.

Eisenlohr, Patrick. 2009. Technologies of the spirit: Devotional Islam, sound reproduction, and the dialectics of mediation and immediacy in Mauritius. Anthropological Theory 9 (3). 273-296.

Elsenlohr, Patrick. 2010. Materialities of entextualization: The domestication of sound reproduction in Mauritian Muslim devotional practices. Journal of Linguistic Anthropology 20(2). 314-333.

Eisenlohr, Patrick. 2011. The anthropology of media and the question of ethnic and religious pluralism. Social Anthropology 19(1). 40-55.

Eisenlohr, Patrick. 2012. Media and religious diversity. Annual Review of Anthropology 41. 37-55.

Eisenlohr, Patrick. 2018. Sounding Islam: Voice, media, and sonic atmospheres in an Indian Ocean world. Oakland: University of California Press. 
El-Tom, Abdullahi. 1985. Drinking the Koran: The meaning of Koranic verses in Berti erasure. Africa 55(4). 414-431.

Engelke, Matthew. 2007. A problem of presence: beyond scripture in an African church. Berkeley, CA: University of California Press.

Engelke, Matthew. 2010. Religion and the media turn: A review essay. American Ethnologist 37(2). 371-379.

Gade, Anna M. 2006. Recitation. In Andrew Rippin (ed.), The Blackwell companion to the Qur'ān, 481-493. Malden, MA: Blackwell.

Gershon, Ilana \& Paul Manning. 2014. Language and media. In N. J. Enfield, Paul Kockelman \& Jack Sidnell (eds.) The Cambridge handbook of linguistic anthropology, 559-576. Cambridge: Cambridge University Press.

Goffman, Erving. 1974. Frame analysis: An essay in the organization of experience. New York: Harper \& Row.

Greene, Paul D. 1999. Sound engineering in a Tamil village: Playing audio cassettes as devotional performance. Ethnomusicology 43(3). 459-489.

Graham, William A. 1993. Traditionalism in Islam: An essay in interpretation. Journal of Interdisciplinary History 23(3). 495-522.

Handman, Courtney. 2015. Critical Christianity: Translation and denominational conflict in Papua New Guinea. Berkeley, CA: University of California Press.

Hanks, William F. 1992. The indexical ground of deictic reference. In Alessandro Duranti \& Charles Goodwin (eds.), Rethinking Context, 43-76. Cambridge: Cambridge University Press.

Harding, Susan F. 2000. The book of Jerry Falwell: Fundamentalist language and politics. Princeton: Princeton University Press.

Harkness, Nicholas. 2014. Songs of Seoul: An ethnography of voice and voicing in Christian South Korea. Berkeley, CA: University of California Press.

Harvey, David. 1989. The condition of postmodernity: An inquiry into the origins of cultural change. Oxford: Blackwell.

Haviland, John. 1996. Projections, transpositions and relativity. In John Gumperz \& Stephen Levinson (eds.), Rethinking linguistic relativity, 271-323. Cambridge: Cambridge University Press.

Hegel, Georg Wilhelm Friedrich. 1970 [1830]. Werke 10: Enzyklopädie der philosophischen Wissenschaften III. Frankfurt am Main: Suhrkamp.

Hegel, Georg Wilhelm Friedrich. 1975 [1835]. Hegel's aesthetics: Lectures on fine art, vol. 1. Translated by T. M. Knox. Oxford: Oxford University Press.

Hegel, Georg Wilhelm Friedrich. 1977. Hegel's phenomenology of spirit. Translated by A. V. Miller. Oxford: Oxford University Press.

Hegel, Georg Wilhelm Friedrich. 1986. Werke 3: Phänomenologie des Geistes. Frankfurt am Main: Suhrkamp.

Hirschkind, Charles. 2006. The ethical soundscape: Cassette sermons and Islamic counterpublics. New York: Columbia University Press.

Hirschkind, Charles \& Brian Larkin. 2008. Introduction: Media and the political forms of religion. Social Text 26(3), issue 96.1-9.

Humboldt, Wilhelm von. 1908. Ober Denken und Sprechen. In Gesammelte Schriften VII.2, edited by the Preussische Akademie der Wissenschaften, 581-583. Berlin: B. Behr.

Irvine, Judith. 1996. Shadow conversations: The indeterminacy of participant roles. In Michael Silverstein \& Greg Urban (eds.), Natural histories of discourse, 131-59. Chicago: University of Chicago Press. 
Jakobson, Roman. 1960. Closing statement: linguistics and poetics. In Thomas A. Sebeok (ed.), Style in language, 350-377. Cambridge, MA: MIT Press.

Jäger, Ludwig. 2000. Die Sprachvergessenheit der Medientheorie. Ein Plädoyer für das Medium Sprache. In W. Kallmeyer (ed.), Sprache und neue Medien, 9-30. Berlin \& New York: De Gruyter.

Kang, Yoonhee. 2006. "Staged" rituals and "veiled" spells: Multiple language ideologies and transformations in Petalangan verbal magic. Journal of Linguistic Anthropology 16(1). 1-22.

Keane, Webb. 1997. Signs of recognition: Powers and hazards of representation in an Indonesian society. Berkeley, CA: University of California Press.

Keane, Webb. 2003. Semiotics and the social analysis of material things. Language \& Communication 23(3). 409-425.

Keane, Webb. 2004. Language and religion. In Alessandro Duranti (ed.), A companion to linguistic anthropology, 431-448. Malden, MA: Blackwell.

Keane, Webb. 2007. Christian moderns: Freedom and fetish in the mission encounter. Berkeley, CA: University of California Press.

Keane, Webb. 2013. On spirit writing: Materialities of language and the religious work of transduction. Journal of the Royal Anthropological Institute 19(1). 1-17.

Kittler, Friedrich. 1993. Draculas Vermächtnis. Technische Schriften. Leipzig: Reclam.

Kittler, Friedrich. 1997. Literature, Media, Information Systems. Edited by John Johnston. Amsterdam: $\mathbf{G}$ and B Arts International.

Krämer, Sibylle. 2000. Das Medium als Spur und als Apparat. In Sibylle Krämer (ed.), Medien, Computer, Realität: Wirklichkeitsvorstellungen und Neue Medien, 73-94. Frankfurt am Main: Suhrkamp.

Krämer, Sibylle. 2008. Medien, Bote, Ubertragung. Kleine Metaphysik der Medialität. Frankfurt am Main: Suhrkamp.

Kuipers, Joel C. 1990. Power in performance: The creation of textual authority in Weyewa ritual speech. Philadelphia: University of Pennsylvania Press.

Latour, Bruno. 2005. Reassembling the social: An introduction to Actor-Network-Theory. Oxford: Oxford University Press.

Levinson, Stephen C. 1988. Putting linguistics on a proper footing: Explorations in Goffman's concepts of participation. In Paul Drew \& Anthony J. Wootton (eds.), Erving Goffman: Exploring the interaction order, 161-227. Cambridge: Polity Press.

Mahmood, Saba. 2001. Rehearsed spontaneity and the conventionality of ritual: Disciplines of salät. American Ethnologist 28(4). 827-853.

Manuel, Peter. 2008. North Indian Sufi popular music in the age of Hindu and Muslim fundamentalism. Ethnomusicology 52(3). 378-400.

McCumber, John. 2006. Sound-tone-word: Toward an Hegelian philosophy of language. In Jere O'Neill Surber (ed.), Hegel and language, 111-125. Albany: State University of New York

Mress. vown, Janet. 2005. Baptismal essentialisms: Giriama code choice and the reification of ethnoreligious boundaries. Journal of Linguistic Anthropology 15(2). 151-170.

McLuhan, Marshall. 1964. Understanding media: The extensions of man. New York \& Toronto: McGraw-Hill.

Mersch, Dieter. 2002. Ereignis und Aura. Untersuchungen zu einer Ästhetik des Performativen. Frankfurt am Main: Suhrkamp.

Meyer, Birgit. 2004. "Praise the Lord": Popular cinema and pentecostalite style in Ghana's new public sphere. American Ethnologist 31(1). 92-110. 
Meyer, Birgit. 2008. Sensational forms: Why media, aesthetics, and power matter in the study of contemporary religion. In Hent de Vries (ed.), Religion: Beyond a concept, 704-723. New York: Fordham University Press.

Meyer, Birgit. 2010. Aesthetics of persuasion: Global Christianity and Pentecostalism's sensational forms. South Atlantic Quarterly 109(4). 741-763.

Meyer, Birgit. 2014. An author meets her critics. Around Birgit Meyer's "Mediation and the genesis of presence: Toward a material approach to religion." Religion and Society: Advances in Research 5(1). 205-254.

Meyer, Birgit \& Dick Houtman. 2012. Introduction: Material religion: How things matter. In Dick Houtman \& Birgit Meyer (eds.), Things: Religion and the question of materiality, 1-26. New York: Fordham University Press.

Meyer, Birgit \& Annelies Moors (eds.). 2006. Religion, media, and the public sphere. Bloomington: Indiana University Press.

Morgan, David. 2005. The sacred gaze: Religious visual culture in theory and practice. Berkeley, CA: University of California Press.

Morgan, David (ed.). 2010. Religion and material culture: The matter of belief. New York: Routledge. Myrvold, Kristina. 2015. The scripture as a living guru: Religious practices among contemporary Sikhs. In Knut A. Jacobsen, Mikhael Aktor \& Kristina Myrvold (eds.), Objects of worship in South Asian religions: Forms, practices and meanings, 163-181. Abingdon \& New York: Routledge.

Oosterbaan, Martijn. 2009. Purity and the devil: Community, media, and the body: Pentecostal adherents in a favela in Rio de Janeiro. In Birgit Meyer (ed.), Aesthetic formations: Media, religion, and the senses, 53-71. New York: Palgrave Macmillan.

Peters, John Durham. 1999. Speaking into the air: A history of the idea of communication. Chicago: University of Chicago Press.

Qureshi, Regula Burckhardt. 1995. Recorded sound and religious music: The case of Qawwali. In Lawrence Babb \& Susan S. Wadley (eds.), Media and the transformation of religion in South Asia, 139-166. Philadelphia: University of Pennsylvania Press.

Robbins, Joel. 2001. God is nothing but talk: Modernity, language, and prayer in a Papua New Guinea society. American Anthropologist 103(4). 901-912.

Saussure, Ferdinand de. 1983. Course in general linguistics. Translated by Roy Harris. La Salle, IL: Open Court.

Schmidt, Leigh Eric. 2000. Hearing things: Religion, illusion, and the American enlightenment. Cambridge, MA: Harvard University Press.

Schulz, Dorothea E. 2008. Soundscape. In David Morgan (ed.), Key words in religion, media and culture, 172-186. New York: Routledge.

Schulz, Dorothea E. 2012. Muslims and new media in West Africa: Pathways to God. Bloomington: Indiana University Press.

Shoaps, Robin A. 2002. "Pray earnestly": The textual construction of personal involvement in Pentecostal prayer and song. Journal of Linguistic Anthropology 12(1). 34-71.

Silverstein, Michael. 2001 [1981]. The limits of awareness. In Alessandro Duranti (ed.), Linguistic anthropology: A reader, 382-401. Malden, MA: Blackwell.

Silverstein, Michael. 2003. Translation, transduction, transformation: Skating glissando on thin semiotic ice. In P. Rubel and A. Rosman (eds.), Translating cultures: Perspectives on translation and anthropology, 75-105. Oxford: Berg.

Simondon, Gilbert. 1992 [1964]. The genesis of the individual. In Jonathan Crary and Sanford Kwinter (eds.), Incorporations, 297-319. New York: Zone. 
Staal, Frits. 1989. Rules without meaning: Ritual, mantras and the human sciences. New York:

Peter Lang

Sterne, Jonathan. 2003. The audible past: Cultural origins of sound reproduction. Durham, NC: Duke University Press.

Stolow, Jeremy. 2005. Religion and/as media. Theory, Culture \& Society 22(4). 119-145.

Tomlinson, John. 1999. Globalization and culture. Chicago: University of Chicago Press.

Tomlinson, Matt. 2004. Ritual, risk and danger: Chain prayers in Fill. American Anthropologist 106(1). 6-16.

Tomlinson, Matt. 2014. Ritual textuality: Pattern and motion in performance. Oxford: Oxford

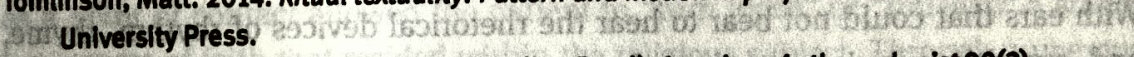
Urban, Greg. 1988. Ritual wailing in Amerindian Brazil. American Anthropologist 90 (2).

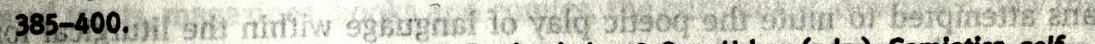
Urban, Greg. 1989. The "I" of discourse. In Benjamin Lee \& Greg Urban (eds.), Semiotics, self, and society, 27-51. Berlin \& New York: Mouton de Gruyter.

Virilio, Paul. 1998. The Virilio reader. Edited by James Der Derian. Malden, MA \& Oxford:

bive Blackwell. Vires, Hent de. 2001. In Media Res: Global religion, public spheres, and the task of

contemporary comparative religious studies. In Hent de Vries a Samuel Weber (eds.). Religion and media, 3-42. Stanford, CA: Stanford University Press.

Weidman, Amanda. 2014. Anthropology and voice. Annual Review of Anthropology 43, 37-51.

Whorf, Benjamin. 1956. Language, thought, and reality: Selected writings. Cambridge, MA: MIT

1ii. Press.

Wice, James.1998. Transforming laments: Performativity and rationalization as linguistlc this ideologles. In Gary B. Palmer \& Debra J. Occhi (eds.), Languages of sentiment, 39-63.

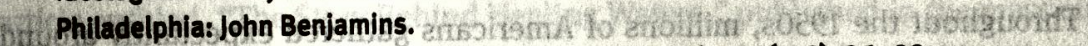

Wilce, James. 1999. Healing. Journal of Linguistic Anthropology 9(1-2). 96-99.

Wilkens, Katharina. 2013. Drinking the Quran, swallowing the Madonna: Embodied aesthetics of popular healing practices. In Afe Adogame, Magnus Echter \& Ollver Frelberger (eds.),

Istec Altemative Voices: A plurality approach for religlous studies: Essays in honor of Uirich

tove Berner, 243-259! Gottingen: Vandenhoeck \& Ruprecht.

Wirtz, Kristina: 2007. How diasporic communities remember: Learning to speak the "tongue of : the oricha" in Cuban Santería. American Ethnologist 34(1). 108-126.

Wolf, Richard K. 2014. The voice in the drum: Music, language, and emotion in Islamicate South Asia. Urbana: University of Illinois Press.

Yelle, Robert A. 2003. Explaining mantras: Ritual, thetoric, and the dream of a natural language

in Hindu Tantra. New York: Routledge. Yelle, Robert A. 2013. The language of disenchantment: Protestant ilteralism and colonial II RSA discourse in British India. New York: Oxford University Press. int traberin jo jiscreityinto

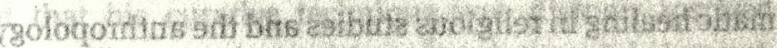

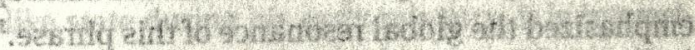




\section{Language and Religion}

Edited by

Robert A. Yelle

Courtney Handman

Christopher I. Lehrich

\section{DE GRUYTER}

MOUTON 
ISBN 978-1-61451-590-6

e-ISBN (PDF) 978-1-61451-432-9

e-ISBN (EPUB) 978-1-5015-0074-9

\section{Library of Congress Control Number: 2018956865}

\section{Bibliographic information published by the Deutsche Nationalbibliothek}

The Deutsche Nationalbibliothek lists this publication in the Deutsche Nationalbibliografie; detailed bibliographic data are available on the Internet at http://dnb.dnb.de.

(c) 2019 Walter de Gruyter Inc., Boston/Berlin Typesetting: Integra Software Services Pvt. Ltd. Printing and binding: $\mathrm{CPI}$ books $\mathrm{GmbH}$, Leck

www.degruyter.com 